Follia Forestalia Polonica, Series A - Forestry, 2020, Vol. 62 (1), 31-38

SHORT COMMUNICATION

DOI: $10.2478 / f f p-2020-0004$

\title{
Forest development and conservation policy in Poland
}

\author{
Hubert Szramka, Krzysztof Adamowicz $\bowtie$ \\ Poznań University of Life Sciences, Faculty of Forestry, Wojska Polskiego 71C, 60-625 Poznań, Poland, \\ e-mail: adamowic@up.poznan.pl
}

\begin{abstract}
Whilst, in many countries, the scale of forest loss from business-as-usual development is immense, in Poland, this problem does not exist. However, obtaining additional land areas for afforestation is a main issue in Poland. In Poland, after the World War II, the forest area has been systematically growing. In 1945, the forest area was about 6.5 million ha, and the forest cover was 21\%. In 2016, the forest area reached 9.2 million ha, and forest cover amounted to $29.5 \%$. Today, there are 0.24 ha of forests per one inhabitant of Poland. The size of wood resources in stands is also changing. In 1945, forest resources on the trunk amounted to approximately 906 million $\mathrm{m}^{3}$, and in 2016, it reached 2.4 million $\mathrm{m}^{3}$. The problem, however, is the uneven distribution of forests in Poland. Forests in Poland are very strictly protected by law. There are two most important acts, Forest Act of 2001 and Nature Conservation Act of 2004, that regulate principles for the retention, protection and augmentation of forest resources. Over the past decades in Poland, the social demands regarding non-economical functions of forest such as recreational activities, soil and water protection and mitigation of global warming became an important and constantly growing challenge for forest managers. Thus we suggest that, first of all, it is very important to extract the leading function for a given forest area. Interactions between development and conservations policies are very tied and may suggest the need of their integration. In this article, we present the concept of development policy for forest management and forest protection in Poland.
\end{abstract}

\section{KeY WORDS}

forest management, forestry policy, environmental protection, forestry protection

\section{INTRODUCTION}

In recent years, various international bodies have developed numerous recommendations concerning sustainable forest economy (Humphreys 1996; Humphreys and Logjam 2006; Solberg et. al 2017). An example in this respect may be provided by the dynamic development of the Forest Europe process. Within this project, 5 working ministerial conferences and an ex- traordinary conference have been held to date. They resulted in the adoption of 4 general declarations, 11 resolutions, 2 decisions as well as the Oslo Ministerial Mandate for Negotiating a Legally Binding Agreement on Forests in Europe. In addition, 2 declarations were issued. At present, 47 signatories participate in the process (the European Union and all the 46 states located either entirely or partly in Europe), as well as 14 states and 45 institutions are observers (http://fores- 
teurope.org). Resolutions and decisions adopted within the Forest Europe process in the years 1998-2015 were presented by Kaliszewski and Gil (2017). International focus on sustainable forest economy has generated increasing interest in research concerning the effect of such systems on forest management on the national scale and on the environment. Studies on the effects of international agreements concerning the implementation of forest economy can be found in professional literature, for example, Underdal (1998, 2002 a, b), Victor et al. (1998), Young (1989, 2001, 2011), Kozuch et al. (2016) and Solberg et al. (2017). In addition, the execution of forest policy is increasingly often connected with the implementation of the climate protection policy. The COP21 or 21st Conference of the Parties to the United Nations Framework Convention on Climate Change in Paris (30 November to 11 December 2015) produced the Paris Climate Agreement. This is a global agreement on the reduction of climate change, limiting global warming to less than $2 \mathrm{C}^{\circ}$ compared to pre-industrial levels and to pursue efforts to limit the increase to $1.5 \mathrm{C}^{\circ}$. In order to keep warming below $2 \mathrm{C}^{\circ}$, we need to limit our annual greenhouse gas emission with an estimate of $9.8 \mathrm{Gt}$ (Young 1989). To accomplish this, the countries have submitted Intended Nationally Determined Contributions (INDCs) outlining their post-2020 climate action.

Public interest in the national policy concerning rational and sustainable forest economy is increasing with the growing interest in forests observed internationally. Poland is a country with the forest cover of approximately $30 \%$. Within the past 20 years, the State Forest Policy has not been updated or adapted either to the changing socio-economic situation of our country or international conditions. The document does not take into consideration, for example, Poland's accession to the European Union in 2004, progressing globalisation or developments in the climate change policy. Moreover, it does not refer to the commitments undertaken by Poland and resulting from our participation in the Ministerial Conference for the Protection of Forests in Europe (MCPFE), currently operating as Forest Europe (Kaliszewski and Gil 2017). On the other hand, Poland is a country that, for years, has been successfully implementing the policy by increasing its forested area as well as forest protection and conservation. These actions result from the long-standing tradition, social awareness, patriotism and a series of legal acts. The Nature Conservation Act and the Act on Forest Development and Conservation constitute legal acts varying in their rank. The Constitution of the Republic of Poland, passed in 1997, does not directly refer to forest protection, but it ensures the right of environmental services to every citizen, whereas, at the same time, it imposes on all citizens the obligation to protect the environment. Specific regulations concerning forest development and conservation are given in the acts and in the respective secondary legislation (implementing regulations) as well as other regulations. Apart from the national legislation, the forest environment is protected, as the common good of the entire mankind, through conventions and international agreements ratified by Poland. In view of the above, it was decided to conduct a scientific evaluation of the forest development and conservation policy implemented in Poland. In the first stage of the study, the status of forest resources in Poland was characterised based on statistical data and available literature. The next stage of the study consisted in analyses of major legislation regulating forest economy and forest conservation in Poland. The following legal acts were analysed: (i) the Act on Forests, (ii) the National Programme for Increasing the Forest Cover, (iii) the State Forest Policy, (iv) the Act on Environmental Protection and (v) the Act on Nature Conservation. The study is based on the scientific analysis of source materials and literature, the analysis of phenomena and economic processes taking place in forestry, the authors' knowledge and a synthesis of research results.

\section{Characteristics OF fOrests IN POLAND}

Poland is a country with an average level of forest resources both on the European and global scale. In 2016, in Poland, the forested area was almost 9.2 million ha forests, of which approximately 7.5 million ha are public forests and approximately 1.7 million ha are private forests. In that year, Poland's forest cover was $29.5 \%$, an equivalent of 0.24 ha forest per capita. Public forests comprise forests owned by the State Treasury (approximately 7.3 million ha, including 7.1 million ha managed by the State Forests Holding) and 186,000 ha in national parks. A detailed list is given in Table 1. 
Table 1. Forest land (as of $31 \mathrm{XII}$ )

\begin{tabular}{|l|c|c|c|c|c|c|}
\hline \multicolumn{1}{|c|}{ Specification } & 1995 & 2000 & 2005 & 2010 & 2015 & 2016 \\
\hline Total in 1,000 ha & 8,946 & 9,059 & 9,200 & 9,329 & 9,420 & 9,435 \\
\hline Forests & 8,756 & 8,865 & 9,000 & 9,121 & 9,215 & 9,230 \\
\hline Public & 7,262 & 7,341 & 7,410 & 7,435 & 7,450 & 7,456 \\
\hline $\begin{array}{l}\text { Owned by State } \\
\text { Treasury }\end{array}$ & 7,186 & 7,262 & 7,328 & 7,351 & 7,345 & 7,351 \\
\hline $\begin{array}{l}\text { Managed by the } \\
\text { State Forests }\end{array}$ & 6,868 & 6,953 & 7,042 & 7,072 & 7,100 & 7,105 \\
\hline National parks & 162 & 181 & 183 & 184 & 185 & 186 \\
\hline Gmina owned & 76 & 79 & 82 & 84 & 84 & 84 \\
\hline Other public & 59 & 59 & 44 & 36 & 49 & 49 \\
\hline Private & 1,494 & 1,524 & 1,590 & 1,686 & 1,765 & 1,774 \\
\hline Forest cover (\%) & 28.0 & 28.4 & 28.8 & 29.2 & 29.5 & 29.5 \\
\hline
\end{tabular}

Source: Central Statistical Office. Forestry. Warsaw, 2017.

After 1945, Poland considerably increased both its forested area and standing timber resources. In 1945, the forested area in Poland was approximately 6.5 million ha and the forest cover was $21 \%$, whereas forest resources amounted to approximately 906 million $\mathrm{m}^{3}$ timber. At present, forest resources are approximately 2.4 billion $\mathrm{m}^{3}$ timber, of which approximately 2 billion $\mathrm{m}^{3}$ was within the State Forests. Moreover, the species composition and age structure of stands have also changed. In $1945,87 \%$ of the area was covered by coniferous species, with deciduous species accounting for $13 \%$. At present, approximately $70 \%$ of the forested area is covered by coniferous species and approximately $30 \%$ by deciduous species. In 1945, stands aged maximum 60 years accounted for approximately $65 \%$ forested area, whereas it is approximately $55 \%$ at present. This indicates an increase in the share of older stands, which, from the economic point of view, is not always desirable. Another characteristic of forestry in Poland is also connected with the uneven distribution of forests throughout the country. The central provinces have a markedly lesser forest cover, amounting to approximately $20 \%$, whereas the northern and western provinces have a greater forest cover, exceeding 30\%. The highest forest cover level of almost $50 \%$ is found in the Lubuskie province, whereas the lowest is recorded in the Łódzkie province with approximately $21 \%$. The mean stand timber resources amount to $266 \mathrm{~m}^{3} /$ ha, with $275 \mathrm{~m}^{3} / \mathrm{ha}$ in public forests and $228 \mathrm{~m}^{3} / \mathrm{ha}$ in private forests. The mean age of stands is 56 years, with 58 years in public forests and 47 years in private forests. Moreover, it needs to be stressed that in the State Forests approximately $52 \%$ of the forests is protection forests and nature reserve forests. In Poland, forests are treated as a national treasure; for this reason, a vast majority of the population (with some exceptions) care for the development and increase in forest resources. Owning a forest in Poland is slowly becoming a status symbol of prosperity and prestige.

\section{DiRECTIONS FOR FOREST DEVELOPMENT AND CONSERVATION IN POLAND}

The major legal acts regulating the directions of forest development and conservation in Poland include the Act on Forests of 1991 (and the State Forest Policy of 1997) and, to a lesser extent, the Act on Nature Conservation of 2004 and the Act on Environmental Protection of 2001.

The Act on Forests defines the principles for the maintenance, protection and increase of forest resources. The act specifies that the primary objectives of forest economy include (i) preservation of forests and their advantageous effect on the climate, air, water, soil, living conditions and human health as well as ecological balance; (ii) conservation of forests, particularly their natural fragments and those of exceptional value thanks to other aspects; (iii) protection of soils and vulnerable areas exposed to increased risk of damage or pollution; (iv) protection of surface and ground waters; and (v) production of timber and other forest products following the principle of sustainable management.

We need to stress the fact that ecological and social goals are priorities over economic objectives. Moreover, the Act on Forests specified the principles for forest economy. The principle of universal forest protection assumes that all forests are subject to protection irrespective of their form of ownership and that all persons are obliged to protect forests. The principle of sustainability of forests and their sustainable management assumes the necessity of on-going regeneration of forest resources, preservation of their biodiversity and genetic richness. The principle of continuity and sustainable utilisation of all forest functions imposes the need for the on-going rational limitation of utilisation of selected forest functions, in order to facilitate such use of other 
functions. The principle of increasing available forest resources is realised based on the afforestation and enhanced productivity of forests - through increased increments in the volume of timber per unit area. The State Forest Policy, adopted by the Council of Ministers in 1997, states that forests are the most natural nature formation inseparably connected with the Polish landscape for ages and as such they are indispensable factors of equilibrium in the natural environment determining the country's development, which justifies the state intervention into the principles of management in forests. The fact that forests serve many vital and diverse functions makes them important elements of Poland's ecological security and, for this reason, the policy and forest economy have the strategic rank comparable to that of military, social or energy security. The forest policy is an integral part of the social, ecological and economic security of Poland. In relation with the increasingly broad range of these social and ecological functions served by forests, the costs of forest economy are increasing accordingly; thus it was decided to assume in the state forest policy the principle of limited self-financing of forestry economic activity, which will require subsidising from special earmarked funds or from the state budget. It was assumed that the complete systemic financing of forest economy by the state budget and special earmarked funds will be implemented by 2020. It seems rather unlikely for this objective to be met by 2020 because of other urgent developmental needs of Poland. That document assumes that Poland will reach the forest cover of $30 \%$ by 2020 and $33 \%$ after 2050 . In order to meet its obligations concerning forest development, Poland adopted a long-term National Programme for Increasing the Forest Cover in 1995, which is being successfully implemented. Table 2 presents the data on afforested area in Poland from 1945 to 2016. It clearly results from these data that the greatest scope of afforestation was observed in the years 1950-1970, with approximately 40,000 ha afforested annually. It was connected with the afforestation of large areas after The Second World War because of war damage, abandoned land and the transfer of rural populations to urban areas. In the years 1971-1995, the process of afforestation slowed down because of a shortage of available land and a lack of incentives for farmers to transfer their land for afforestation purposes. In 2001, in Poland, the Act on Allocation of Farmland to Afforestation was passed,
Table 2. Afforestation of land in Poland in 1945-2016

\begin{tabular}{|c|c|c|c|}
\hline \multirow{3}{*}{$\begin{array}{l}\text { Specifica- } \\
\text { tions }\end{array}$} & \multirow[b]{2}{*}{ Total } & \multicolumn{2}{|c|}{ Forests } \\
\hline & & $\begin{array}{c}\text { of the State } \\
\text { Treasury }\end{array}$ & $\begin{array}{l}\text { Not owned by the } \\
\text { State Treasury }\end{array}$ \\
\hline & \multicolumn{3}{|c|}{ in 1,000 ha } \\
\hline $1945-1949$ & 67.0 & 58.4 & 8.6 \\
\hline $1950-1955$ & 185.7 & 93.1 & 92.6 \\
\hline $1956-1960$ & 226.5 & 114.5 & 112.0 \\
\hline $1961-1965$ & 277.6 & 152.1 & 125.5 \\
\hline $1966-1970$ & 176.7 & 106.0 & 70.7 \\
\hline $1971-1975$ & 94.1 & 55.5 & 38.6 \\
\hline $1976-1980$ & 78.5 & 47.5 & 31.0 \\
\hline 1981-1985 & 31.7 & 21.2 & 10.5 \\
\hline 1986-1990 & 35.9 & 21.6 & 14.3 \\
\hline 1991-1995 & 53.4 & 35.2 & 18.2 \\
\hline 1996-2000 & 95.7 & 58.2 & 37.5 \\
\hline 2001-2005 & 95.4 & 46.3 & 49.1 \\
\hline 2006-2010 & 49.6 & 12.9 & 36.7 \\
\hline $2011-2015$ & 20.4 & 2.9 & 17.5 \\
\hline 2016 & 2.0 & 0.6 & 1.4 \\
\hline 1945-2016 & 1490.2 & 826.0 & 664.1 \\
\hline
\end{tabular}

Source: Central Statistical Office. Forestry. Warsaw, 2017.

which introduced financial incentives for farmers allocating their land for afforestation. This resulted in a short-term increase in the afforestation rate. Starting from 2004, that is, Poland's accession to the European Union, farmers have been able to use EU programmes promoting afforestation within the framework of the rural development programme. However, the simultaneous development of residential housing sector and road construction projects as well as the service sector has hindered the process of land transfer for afforestation. At present, approximately 2,000 ha are afforested annually. At the same time, Poland has very strict regulations concerning the conversion of forest land to allocate it to other forms of land use. Thus the deforested area is small, amounting to approximately 500 ha annually. Detailed data are given in Table 3. The major types of deforested areas include sand and gravel mines, excavations of mineral deposits as well as land allocated for industrial development. The Act on Nature Conservation of 16 April 2004 concerns the protection of trees and shrubs growing outside forests. Nature conservation, 
Table 3. Forest land designated for non-forest purposes in Poland

\begin{tabular}{|c|c|c|c|c|}
\hline \multirow{2}{*}{ Specifications } & 2005 & 2010 & 2015 & 2016 \\
\hline & \multicolumn{4}{|c|}{ ha } \\
\hline Total & 472 & 551 & 738 & 447 \\
\hline Forests: public & 310 & 412 & 413 & 181 \\
\hline private & 162 & 139 & 325 & 266 \\
\hline \multicolumn{5}{|l|}{ Directions of designation } \\
\hline Minerals & 222 & 330 & 442 & 218 \\
\hline Areas: industrial & 78 & 88 & 121 & 106 \\
\hline communication & 41 & 24 & 10 & 6 \\
\hline residential & 26 & 41 & 36 & 30 \\
\hline $\begin{array}{l}\text { reservoirs and } \\
\text { water devices }\end{array}$ & 4 & 4 & 0.4 & 0.2 \\
\hline others & 101 & 65 & 128 & 87 \\
\hline
\end{tabular}

Source: Central Statistical Office. Forestry. Warsaw, 2017.

within the meaning of that act, consists in the preservation, sustainable use and restoration of resources, creations and components of nature such as plants, animals, fungi, habitats, landscapes, urban and rural green areas as well as tree plantings. The commune councils are required to establish and properly maintain green areas and tree plantings. Land owners have to obtain a permit to remove trees and shrubs subject to adequate fees. In the case of tree or shrub removal without the required permit, the commune authorities impose financial fines. Fees for the removal of trees and shrubs as well as fines for their unauthorised removal are dependent on the type and species of the tree and stem circumference.

\section{Discussion}

European forests co-evolved with humans since the beginning of the Holocene, and their current distribution, structure and dynamics represent a long history of clearing, alteration and management (Fuchs et. al 2008; Kaplan 2009; Kaplan et. al. 2012). Shaped by human activities, forests were a main sector of the economy providing food (e.g. hunting, livestock grazing and plant products), timber products (e.g. lumber for construction and naval fleets and pulp for paper), fuel (e.g. firewood and charcoal) and other important resources (e.g. potash and tar). The importance of forest resources, which can be quickly exhausted by unrestricted use, provided the impetus for forest mapping, inventory and management. Forests in Poland are subject to public interest. They are protected by several legal acts passed by the parliament, mainly the Act on Forests of 1991and the Act on National Strategic Resources of 2001. Moreover, the State Forest Policy of 1997 and the National Programme for Increasing the Forest Cover of 1995 propose solutions stimulating the development of forests and forestry in Poland. Both the National Programme for Increasing the Forest Cover and the State Forest Policy assume an increase in Poland's forest cover to 30\% in 2020 and 33\% after 2050. These programmes seem feasible, although we face increasing problems with their implementation. As it was reported by Kaliszewski (2016), the problem with further execution of afforestation programmes results from a lack of available land for afforestation. This is a consequence of direct payments within the framework of the EU subsidies to agricultural production, no possibilities for afforestation of permanent grassland and limited afforestation potential in the Natura 2000 areas. In the opinion of the authors of this study and other researchers, Poland's forest cover exceeds by approximately $2 \%$ the level officially recorded by the Main Statistical Office. This results from considerable problems and costs related with the conversion of farmland to forest and still greater difficulties faced when converting forest land to farmland or plots for development investments. For this reason, land owners frequently do not notify the authorities of afforestation they have performed or that resulting from natural succession. The actual forest cover in Poland in 2014 was already $32 \%$. Moreover, some authors indicated the problem with an adequate definition of forest, which also affects the value of the forest cover index. In Poland, forests are protected within the framework of three groups of functions, that is, productive, ecological and social (Zając 2001; Płotkowski 2004; 2008; Zając and Gołos 2008; Adamowicz and Kaciunka 2014; Kaliszewski and Młynarski 2014; Adamowicz et. al 2015; Kaliszewski 2016; Szramka et al. 2016). The basis of planning (not only in forestry) is making decisions about actions to be taken in the future, including knowledge about the past and present. Planning in forest management is commonly determined by minated paradigm and goals of its implementation (Adamowicz et. al 2016; Robinson et al. 2016). Within the productive function of forests, all 
forestry operations are planned so that they promote the development and protection of existing resources. This is confirmed by an increase in the forest area in Poland from 6.5 million ha in 1945 to 9.2 million ha in 2016, an increase in standing timber resources from 906 million $\mathrm{m}^{3}$ in 1945 to 2.4 billion $\mathrm{m}^{3}$ in 2016 as well as an increase in the forest cover from approximately $21 \%$ to approximately $30 \%$. It results from a study by Szramka (2008) that in 1951-1975 (analyses concerned 5-year periods), the volume of harvested timber slightly exceeded $70 \%$ of the current volume increment only in one 5 -year period. At present, in Poland, approximately $60 \%$ of the timber volume increment is harvested. One of the pillars of the Polish economy is the wood industry. Its share in the sold production of the entire processing industry is around $10 \%$. The consumption of wood products is constantly growing, and thus the role of the wood industry in the national economy is also growing (Adamowicz and Noga 2014). Within the framework of ecological functions, Poland is starting to refrain from harvesting timber in areas of nature value, creating the so-called ecological areas, and in areas, in which forests were damaged on a wide scale by winds, in the most valuable fragments, the so-called reference areas are formed, in which processes of natural forest regeneration are observed and investigated. Moreover, in traditional felling areas, clusters of trees and shrubs are left until their natural decomposition. Within the framework of social functions, special forest parking facilities, forest education centres as well as cycling, horse-riding and walking trails are established to ensure safe and organised opportunities to use the forest value. Moreover, forestry is an important element in rural development, as it has been indicated by several authors, for example, Adamowicz (2005, 2008), Szramka (2005, 2006, 2008), Liu et al. (2018), Pereira and Martinho (2017) and Bjarstig and Stens (2018). The forest offers jobs to the local residents, primarily in rural areas. Moreover, Poland has a longterm tradition of picking wild mushrooms and fruit for family needs, which, apart from their tangible material value, offers an opportunity to rest and relax in the forest. At present, in Poland, the focus is definitely on the performance of social functions, while still considering economic and ecological functions. Several documents and publications, for example, the State Forest Policy of 1997, indicate a conflict between forest functions. We are of an opinion that this is an overgeneralisation, be- cause there is no conflict between forest functions. The forest serves all these functions simultaneously, but to a varying degree, whether or not we specifically name them. These functions exist, and they are fulfilled. Obviously, the use of some functions to a certain extent limits the use of other functions in the same area and in the same period. In contrast, there is a conflict between expectations of various social groups concerning forests; for this reason, it seems advisable to identify a leading function in a given forest area for which it will be the primary function and treat the other functions as subordinate to the leading function. This should result in the alleviation of social conflicts in view of the opportunity to use non-productive forest functions, which is an important goal for the multi-functional and sustainable forestry in Poland.

\section{Concluding Remarks}

In Poland, we do not observe the problem of deforestation or a decrease in forest area. Since WWII, the forested area, the volume of standing timber resources and forest cover in Poland have been systematically increasing. After 1945, on an average, the forested area increased by approximately 20,000 ha annually. At present, this process has slowed down, because approximately 2,000 ha are afforested annually. Owing to considerable problems and costs, a slight share of forested area is allocated to other uses. In 2005-2015, the average annual deforested area was approximately 550 ha, whereas in 2016, it was only approximately 450 ha. As a result, the forest cover of Poland has been systematically increasing. We may also observe a continuous forest development in terms of an increase in standing timber resources. At present, it is approximately 2.4 billion $\mathrm{m}^{3}$ timber. In the early $1990 \mathrm{~s}$, it was decided to abandon the raw material-centred management and the principles of sustainable and multifunctional forest economy are now being successfully implemented. At present, apart from the economic function yielding approximately 40 million $\mathrm{m}^{3}$ timber and providing jobs for approximately 27,000 employees, social and ecological functions are also successfully fulfilled. Forest development is financed almost solely from the funds of the State Forests economic activity, because very few other sources of funding are available. Since 2010, the State 
Forests have not received funds from the state budget to execute the National Programme for Increasing the Forest Cover. Moreover, private forest owners and local government bodies are not very willing to allocate land for afforestation. Thanks to the well-established social awareness, educated forestry workers and great respect for forests resulting from our historical traditions, the area of forests has been increasing in Poland and foresters as work force are well perceived by the general public.

\section{References}

Adamowicz, K., Kaciunka H. 2014. Evaluating variation in logged timber costs and raw timber prices during the period, 2001-2009 for the Regional Directorate of the State Forests in Zielona Góra. Leśne Prace Badawcze, 75, 55-60.

Adamowicz, K., Noga, T. 2014. Multivariate analysis of bankruptcy in companies in the wood sector Sylwan, 158 (9), 643-650.

Adamowicz, K. 2005. An attempt to estimate the role of afforestation in the agrarian policy and development of rural areas in Poland. Roczniki Naukowe SERiA, 7 (4), 9-13.

Adamowicz, K. 2008. The Development of rural areas in context of changes of timber market in Poland. Prace Naukowe Akademii Ekonomicznej we Wrocławiu, 1192, 149-156.

Adamowicz, K. et al. 2015. An attempt at valuation of wood from dead trees in Polish forests. Acta Scientiarum Polonorum Silvarum Colendarum Ratio et Industria Lignaria, 14 (1), 5-13.

Adamowicz, K., Kożuch, A., Jaszczak, R. 2016. Application of an ex post analysis for the preparation of the economic annex to the forest management plan. Sylwan, 160 (11), 883-892.

Bjarstig, T., Stens, A. 2018. Social values of forests and production of new goods and services: the views of Swedish family forest owners. Small-Scale Forest$r y, 17$ (1), 125-146.

Fuchs, R., Herold, M., Verburg, P.H., Clevers, J.G.P.W. 2013. A high-resolution and harmonized model approach for reconstructing and analyzing historic land changes in Europe. Biogeosciences, 10, 1543-1559.
Humphreys, D. 1996. Forest politics: the evolution of international cooperation. Earthscan Publications, London England.

Humphreys, D. 2006. Logjam: deforestation and the crisis of global governance. Earthscan, London, England.

Kaliszewski, A., Gil, W. 2017. Goals and priorities of the 'National Forest Policy' in the light of the Forest Europe (formerly MCPFE) commitments. Sylwan, 161 (8), 648-658.

Kaliszewski, A., Młynarski, W. 2014. Direct costs and sources of financing of nature conservation and biodiversity protection in forest districts in the Mazowieckie Province. Sylwan, 158 (7), 491-498.

Kaliszewski, A. 2016. National Program for Expanding of Forest Cover - implementation and its diffi culties from a local view. Studia i Materiaty Centrum Edukacji Przyrodniczo-Leśnej w Rogowie, 18, 7-19.

Kaplan, J.O., Krumhardt, K.M., Zimmermann, N.E. 2012. The effects of land use and climate change on the carbon cycle of Europe over the past 500 years. Global Change Biology, 18, 902-914.

Kaplan, J.O., Krumhardt, K.M., Zimmermann, N. 2009. The prehistoric and preindustrial deforestation of Europe. Quaternary Science Reviews, 28, 3016-3034.

Krajowy program zwiększania lesistości. Available at https://www.mos.gov.pl/fileadmin/user_upload/ mos/srodowisko/lesnictwo/Krajowy_Program Zwiekszania_Lesistosci.pdf (accessed on 8 May 2018).

Kożuch A., Adamowicz K. 2016. Effect of costs incurred on the development of non-productive forest functions on the economic situation in forest districts in the Regional Directorate of the State Forests in Kraków. Sylwan, 160 (2), 1010-1019.

Liu, Y., Yao, S.B., Lin, Y. 2018. Effect of Key Priority Forestry Programs on off-farm employment: Evidence from Chinese rural households. Forest Policy and Economics, 88, 24-37.

Pereira, V.J., Martinho, D. 2017. Insights from over 30 years of common agricultural policy in Portugal. Outlook on Agriculture, 46 (3), 223-229.

Płotkowski, L. 2004. Key issues in the forest sector today. Sylwan, 148 (11), 22-36.

Płotkowski, L. 2008. Economical forest functions evaluation or economic elements of sustainable forest 
management. Studia i Materiaty Centrum Edukacji Przyrodniczo-Leśnej w Rogowie, 19, 252-272.

Polityka leśna państwa. Available at https://www.mos. gov.pl/g2/big/2009_04/34ba398d45e363aed16d2ad 3b015136a.pdf (accessed on 8 May 2018).

Robinson, A. P., McLarin, M., Moss, I. 2016. A simple way to incorporate uncertainty and risk into forest harvest scheduling. Forest Ecology and Management, 359, 11-18.

Solberg, B., Bergseng E., Lindstad, B.H. 2017. Assessing national impacts of international environmental regimes for biodiversity protection and climate mitigatio in boreal forestry - Experiences from using a quantitative approach. Forest Policy and Economics, 85, 147-160.

Szramka, H. 2005. Forest policy and its influence on development of rural areas in Poland. Roczniki Naukowe SERiA, 7 (4), 408-411.

Szramka, H. 2006. Forest policy and its influence on development of rural areas in Poland. Roczniki Naukowe SERiA, 7 (4), 337-341.

Szramka, H. 2008. The role of forest management in the development of rural areas in Poland. Prace Naukowe Akademii Ekonomicznej we Wrocławiu, 1112, 137-141.

Szramka, H., Starosta-Grala, M., Adamowicz, K. 2016. Forestry in sectoral economic development in Poland. Sylwan, 160 (5), 416-423.

Underdal, A. 1998. Explaining compliance and defection: three models. European Journal of International Relations, 4, 5-30.

Underdal, A. 2002a. Methods of analysis. In: Environmental Regime Effectiveness (ed.: E.L. Miles, ). MIT Press, Cambridge, 47-59.

Underdal, A. 2002b. One Question, Two Answers. In: Environmental Regime Effectiveness (ed.: E.L. Miles). MIT Press, Cambridge, 3-45.

Ustawa z dnia 16 kwietnia 2004 r. o ochronie przyrody. Dz.U. 2009 r. nr 151, poz. 1220. Available at http://
prawo.sejm.gov.pl/isap.nsf/DocDetails.xsp?id =WDU20040920880 (accessed on 8 May 2018).

Ustawa z dnia 27 kwietnia 2001 r. prawo ochrony środowiska. Dz. U. 2001, nr 62, poz. 627. Available at http://prawo.sejm.gov.pl/isap.nsf/DocDetails. xsp?id=WDU20010620627 (accessed on 8 May 2018).

Ustawa z dnia 28 września 1991 r. o lasach. Dz. U. 1991 r. nr 101., poz. 444. Available at http://prawo.sejm.gov. pl/isap.nsf/DocDetails.xsp?id=WDU19911010444 (accessed on 8 May 2018).

Ustawa z dnia 6 lipca 2001 r. o zachowaniu narodowego charakteru strategicznych zasobów naturalnych kraju. Dz. U. 2001 r. nr 97, poz. 1051. Available at http://prawo.sejm.gov.pl/isap.nsf/DocDetails. xsp?id=WDU20010971051 (accessed on 8 May 2018).

Victor, D.G., Raustiala, K., Skolnikoff, E.B. 1998. The implementation and effectiveness of international environmental commitments: theory and practice. International Institute for Applied Systems Analysis, Cambridge.

Young, O.R. 1989. International cooperation: building regimes for natural resources and the environment. Cornell University Press, Ithaca, N.Y.

Young, O.R. 2001. Inferences and indices: evaluating the effectiveness of international environmental regimes. Global Environmental Politics, 1, 99-121.

Young, O.R. 2011. Effectiveness of international environmental regimes: existing knowledge, cuttingedge themes, and research strategies. PNAS, 108 (50), 19852-19860.

Zając, S., Gołos, P. 2008. The role of forestry in the socio-economic development of Poland's agricultural region (input-output analysis). Folia Forestalia Polonica, Series A - Forestry, 49-50, 65-76.

Zając, S. 2001. Forests and forestry in the countries of Central and Eastern Europe - transformation process and challenges. Prace IBL, Ser. A, 4, 71-77. 